\title{
Self-Knowledge and Reditio Completa: Two Mid- 13th-Century Interpretations of the Liber de causis, prop. XIV(Xv) (Roger Bacon, Ps.-Henry of Ghent)
}

\author{
Thérèse Scarpelli Cory \\ University of Notre Dame
}

"Every knower knows its essence and therefore returns to its essence with a complete return" (omnis sciens scit essentiam suam, ergo est rediens ad essentiam suam reditione completa). ${ }^{1}$ The influence of the Liber de causis on Scholastic theories of intellect has been overshadowed by its important contributions to the history of metaphysics and theology in medieval Europe. The doctrine of prop. $\mathrm{XIV}(\mathrm{XV})$, however, with its distinctive imagery of "complete return" (reditio completa), frequently cited in Latin Scholastic discussions of self-knowledge, offers us an accessible vantage point from which to begin evaluating the ways in which the Liber's theory of the intellect was understood and incorporated into medieval Scholasticism. ${ }^{2}$

Here I will examine the treatment of prop. $\operatorname{XIV}(\mathrm{XV})$ in two questioncommentaries on the Liber de causis. The first is Roger Bacon's Questiones supra Librum de causis, which dates from the late 1240 os in Paris. ${ }^{3}$ The second is the Quaestiones in Librum de causis of uncertain authorship, likely composed after 1245 (since it is evidently dependent on Bacon's commentary) but before ${ }_{125} 6$ (since it reflects the so-called "first Averroism"). Grabmann assigned the text to Henry of Ghent's early teaching years in Paris, but the author usually goes by

1 Liber de causis, prop. XIV(Xv); for complete text, see note 17 below. Thanks go to Dragos Calma and Rega Wood for comments, and to Joshua Lim for assistance preparing the manuscript.

2 On the reditio completa, see Cory 2017; Baumgarten 2014, p. 23-47; Still 1999, p. 123-131; Putallaz 1991a, p. 168-172 and 189-202; and Fetz 1975.

3 Edited in 1935 by Steel and Delorme, who suggest a composition date of 1245 . Silvia Donati pushes the date forward slightly to sometime after 1246/47; see her groundbreaking article, Donati 2013, p. 157 and 159-162. Regarding place of composition, there seems to be general agreement that Bacon was in Paris at least during 1242-1248: see Hackett 2015; in any case the ideas from this commentary certainly circulated in Paris, given the influence on Ps.-Henry and perhaps the early Aquinas. For a brief and not very illuminating summary of our topic in Bacon, see Wrobel 1979 . 
"Ps.-Henry of Ghent," not because Henry's authorship has been disproven, but because Grabmann's evidence remains slim and inconclusive. ${ }^{4}$

The time-period represented by these two commentaries, the late 1240 os and perhaps early 125os, is particularly interesting for two reasons. First, it is in March 1255 that a seven-week reading of the Liber de causis is first known to be required in the curriculum of the Paris Faculty of Arts. So our two commentaries are representative of a period in which the reading of the Liber was driven by a faculty interest that must have eventually been influential in motivating the inclusion of the Liber within the official Arts curriculum. In fact, both our commentaries are likely reportationes of lectures given at the University of Paris, and if the dating is correct, they represent the two earliest known Latin commentaries on the Liber de causis. Second, the 1240 and 125 os witnessed interesting and significant developments in Scholastic treatments of self-knowledge, in which an earlier project of distinguishing two or three types of self-knowledge blossomed into a project of explaining how these selfknowing acts occur. So Bacon's and Ps.-Henry's comments on the Liber's prop. $\mathrm{XIV}(\mathrm{XV})$ offer a window onto the evolution of these new conceptual frameworks to explain the implications of self-presence for self-knowing, the nature of consciousness and self-consciousness, and the possibility of sense reflexivity.

I will proceed as follows: First, I will lay out the historical-doctrinal context that will help clarify the issues that Bacon and Ps.-Henry raise in connection with the Liber's prop. $\operatorname{xIV}(\mathrm{xV})$. The second section presents, in table form, a structural division of Bacon's and Ps.-Henry's comments on prop. $\operatorname{XIV}(\mathrm{XV})$ and a doctrinal summary. In the third and fourth sections, I will discuss the doctrinal claims about self-knowledge and reditio completa made in each commentary on prop. $\operatorname{XIV}(\mathrm{XV})$, one at a time. Finally, I will conclude with some broader reflections on the history of medieval thought on self-knowledge and self-consciousness.

4 Edited in 1974 by Zwaenepoel. The editor (p. 14-15) justifies this date in view of the commentary's evident dependence on Roger Bacon's commentary, and its attribution to Averroes of a view according to which the possible and agent intellect can be considered in two ways, both as intelligences existing separately, and as powers of individual human souls - an interpretation of Averroes that evaporated by the mid-125os, after Averroes's monopsychist commitments became evident. The editor observes that Grabmann's attribution to Henry of Ghent rests on "un faible indice indirect," although it cannot be positively ruled out (p. 15). For general discussion of Bacon's and Ps.-Henry's approaches to the Liber de causis in their commentaries, and what it meant concretely for them to consider the text as belonging to the Aristotelian tradition, see D'Ancona 1995, which also very briefly summarizes their treatments of prop. $\mathrm{XIV}(\mathrm{XV})$. 


\section{Historical Context: Mid-Thirteenth-Century Debates on Self-Knowledge}

With the wave of Arabic-to-Latin translations in the late 12th and early 13th century, Latin reflection on self-knowledge entered a new phase. ${ }^{5}$ The 12thcentury approach to self-knowledge is reflected in a set of Cistercian treatises on the soul-i.e., William of St.-Thierry's De natura corporis et anima, Isaac of Stella's Epistola de anima, and the highly influential anonymous Liber de spiritu et anima - which urge the practice of self-knowledge, and particularly the knowledge of the soul's nature, as a path to ethical perfection. By lifting up its gaze from the material to the immaterial realm and pondering the immaterial nature of one's own soul, the mind purifies its concepts, so that it can begin thinking in a more fitting way about the purely immaterial God. The newlytranslated texts of Avicenna, Aristotle, and Averroes, however, spurred among early 13th-century thinkers a more psychological analysis of self-knowledge as a phenomenon to be explained, a theme for study in its own right.

Without giving a reductive impression of the highly complicated debate that ensued, I want to highlight just two important problems which will help us make sense of Bacon's and Ps.-Henry's comments on prop. XIV(XV): (1) the implications of the soul's self-presence for its self-knowledge; and (2) the explanation of what makes a cognitive act be a conscious or fully attentive act. Broadly speaking, over the course of the thirteenth century, the debate's center of gravity shifted gradually (if irregularly) from the first, more metaphysicallyoriented, concern, to the second, more phenomenologically-oriented, concern. The two issues, however, are closely linked. Indeed, I think that our two midthirteenth-century commentaries precisely offer a window onto the process whereby the standard distinctions proposed in answer to the first problem naturally raised questions which led to the formulation of the second problem. In fact, one could perhaps interpret each problem as representing different angles of approach to a fundamental problem about cognition: namely, must cognitive activity always be an act of attending to something? Or does cognitive activity unfold across a spectrum of activities that are unconscious, subconscious, liminally conscious, partially conscious, etc.?

5 Further discussion of the mid-thirteenth-century debate, and development in Thomas Aquinas's thought on the matter can be found in chs. 1-2 of Cory 2014. For a comprehensive overview of varying attitudes throughout the 13th century toward what I call below the Self-Presence Thesis, see Köhler 200o, p. 534-583, with brief summaries of the positions in our two Liber commentaries on p. 550-551. 
Let us take a closer look, then, at the first issue. Early Scholastic treatments of self-knowledge were especially focused on establishing what we can call the "Self-Presence Thesis":

Self-Presence Thesis: Intellectual entities or souls are always innately and necessarily self-knowing, regardless of whether the soul is actually thinking about itself or distracted by sensory objects.

The usual argument for the Self-Presence Thesis runs along the following lines: An intellect's ignorance of some entity is remediated when the entity becomes present to that intellect. But I am already present to myself, because I am myself! Hence, I cannot be ignorant of myself. But if I am not ignorant of myself, then I know myself. Therefore, I always know myself in some fundamental sense, whether I realize it or not. This self-knowledge is described as knowing oneself per essentiam suam or per praesentiam suam, because the intellect does not need anything else (e.g., a species or an act or a process of reasoning) to become present to itself: It satisfies in its very essence the sufficient condition for its knowing itself, because it is itself.

The Self-Presence Thesis's popularity seems to be at least partially attributable to Latin readings of Avicenna's Liber de anima, with its vivid image of the "Flying Man," whose soul is permanently self-knowing despite a lack of any other cognitive activity. ${ }^{6}$ Avicenna's "Flying Man" easily suggests to readers that the human soul innately knows itself whether it notices itself doing so or not. The Self-Presence Thesis was the centerpiece of treatments of self-knowledge and applied to all intellectual beings, including human souls, especially in the

6 This approach is also, of course, Augustinian, and Augustine is more often cited in support of the Self-Presence Thesis than Avicenna is. Scholastic authors frequently cited Augustine, De Trinitate 14.6.9 as a maxim articulating how the mind's permanent essential self-knowing could be distinguished from occasional acts of thinking about oneself (p. 432): Sed quoniam mentem semper sui meminisse semperque se ipsam intellegere et amare, quamuis non semper se cogitare discretam ab eis quae non sunt quod ipsa est, quaerendum est quonam modo ad cogitationem pertineat intellectus, notitia uero cuiusque rei quae inest menti etiam quando non de ipsa cogitatur ad solam dicatur memoriam pertinere. The Self-Presence Thesis was also expressed in the anonymous Liber de spiritu et anima, c. 6 (Migne, vol. 40, col. 783), which circulated under an attribution to Augustine (see, e.g., the citation in John de la Rochelle, note 7 below). Nonetheless, the Self-Presence Thesis is not widely thematized prior to the translation of Avicenna's Liber de anima. I am inclined to think, without being able to prove it definitively, that Avicenna's "Flying Man" made the thesis theoretically significant for his Latin readers, consequently drawing their attention to parallel ideas in Augustine, who then became the main authoritative source for this thesis in the subsequent debates. 
123os, e.g., in William of Auvergne and Jean de la Rochelle. ${ }^{7}$ But in the 1240s125 os the Self-Presence Thesis is beginning to weaken. Its application to human souls was explicitly rejected by Thomas Aquinas in De veritate 10.8 (1258-1259), reversing a position he had acquired from Albert and repeated in his Sentences commentary. ${ }^{8}$ But as we will see, Bacon and Ps.-Henry already anticipate this move: In their comments on the Liber's prop. XIV(XV), they explicitly endorse the Self-Presence Thesis with respect to intelligences, but it is conspicuously absent from their account of human souls (though they do not explicitly reject its application to souls either). As it seems, then, Bacon and Ps.-Henry associate the Self-Presence Thesis with the Liber's prop. XII(XIII)'s comments about separate intelligences, and they do not explicitly take prop. $\mathrm{XIV}(\mathrm{XV})$ as a statement of the Self-Presence Thesis.

Now for defenders of the Self-Presence Thesis, it was crucial to distinguish between knowing oneself "by one's presence" (a kind of permanent nonconscious cognitive activity) and thinking about oneself. Even if the soul's self-

7 See, e.g., Jean de la Rochelle, Liber de anima 1.1, p. 51, 1. 42-52, l. 47: Item, Augustinus in libro De anima et spiritu: 'Nichil tam nouit mens uel anima quam id quod sibi presto est; nec menti nec anime quicquam magis presto est quam ipsa sibi. Ergo nichil tam nouit quam se: cognoscit enim uiuere se, meminisse se, uelle, cognoscere, scire, iudicare; et hec omnia certissime nouit de se.' Impossibile est igitur quod ignoret se esse. William of Auvergne, De anima 3.12, vol. 2, p. 103: Declaratum etiam est tibiquod nullus homo permittitur ignorare animam suam, cum tot et tanta ac talia de ipsa cognoscere necesse habeat propter ipsam suae praesentiam veritatis quae nullo modorum ipsam ignorare animam suam pati possunt.

8 Thomas Aquinas, Sentences 1.3.4.5, p. 122: Dico ergo, quod anima non semper cogitat et discernit de Deo, nec de se, quia sic quilibet sciret naturaliter totam naturam animae suae, ad quod vix magno studio pervenitur: ad talem enim cognitionem non sufficit praesentia rei quolibet modo; sed oportet ut sit ibi in ratione objecti, et exigitur intentio cognoscentis. Sed secundum quod intelligere nihil aliud dicit quam intuitum, qui nihil aliud est quam praesentia intelligibilis ad intellectum quocumque modo, sic anima semper intelligit se et Deum. Compare De veritate 10.8, p. 321, 1. 234-322, 1. 314: Sed quantum ad habitualem cognitionem, sic dico, quod anima per essentiam suam se videt, id est, ex hoc ipso quod essentia sua est sibi praesens, est potens exire in actum cognitionis sui ipsius. [...] Sic ergo patet quod mens nostra cognoscit se ipsam quodam modo per essentiam suam, ut Augustinus dicit. And ad 4 (p. 325, l. 500-503): [A]nima est sibi ipsi praesens ut intelligibilis, id est ut intelligi possit, non autem ut per se ipsam intelligatur sed ex obiecto suo, ut dictum est. In other words: Self-presence entails an activity of self-understanding in the Sentences text, but only a habit or disposition for self-understanding in the De veritate text, as argued in Cory 2014, chs 2 and 5 . This is the solution already found in Bonaventure, Sentences I.3.2.2.2, ad 3 (p. 92, where it appears as the second half of ad 2), a work dating to 1250-1252: Per hoc enim, quod anima sibi praesens est, habet notitiam; per hoc, quod est unum sibi, habet habitum amoris: et ideo, sicut potentiae sunt consubstantiales animae, ut supra visum est, ita et huiusmodi habitus. Bonaventure, however, like Bacon and Ps.-Henry, does not explicitly reject that presence can be cashed out in terms of an actual self-understanding. 
presence is sufficient for a non-conscious self-knowing, it is obviously not sufficient for the soul's thinking about or being aware of itself. ${ }^{9}$ Otherwise I would always be thinking about myself. But in the 1240s-125os, there is a growing tendency to try to explain why there is a difference between these two modes of self-knowing (and even to identify new modes of self-knowing), using Aristotelian concepts such as habit vs. act, or the intellect's becoming intelligible in knowing the intelligible, or the notion of knowing the soul by reasoning from objects to acts to powers to essence. ${ }^{10}$

Thus a new concern arose: how could one account for the difference between acts of thinking about oneself, and the more basic kind of self-knowing that the soul has apart from such acts? This new endeavor drew Latin authors' attention to the conscious aspects of intellectual activity, broaching the second key problem relevant to our inquiry: What are the conditions under which cognitive activity constitutes a full and explicit, attentive awareness of something? Various answers were developed, ${ }^{11}$ one of which can be formulated as the Higher-Order Thesis:

Higher-Order Thesis: In order for me to be aware of $x$, I must not only have an act of understanding $x$ (a "simple," "direct," or "first-order" act), but also have an act of understanding my understanding of $x$ (in a "complex," "reflex," or "second-order" act). ${ }^{12}$

The Higher-Order Thesis proposes an account of why certain cognitive acts are conscious and others are not. It was advanced by Henry of Ghent in the 1270s128 os, and was more famously defended by Scotus and Ockham (with Chatton as a strenuous opponent) in the 14 th century. ${ }^{13}$ So it is interesting to see that

9 The distinction was suggested by Augustine; see note 6 above.

10 See e.g., Albertus Magnus, De homine (p. 446-447 and p. 551-553), composed 1241-1242, and Commentary on the Sentences I.3.H.29, composed 1243-1249; Bonaventure, Commentary on the Sentences I.3.2.2.1-2 and III.27, dub. 3 (written 1250-1252 and revised 1254-1257); Aquinas, Commentary on the Sentences I.3.4.5 (composed c. 1252-1256) and De veritate 10.8 (from 1257-1258).

11 See, e.g., the distinction between implicit and explicit self-awareness in Albert and Aquinas (which coexists alongside the Self-Presence Thesis in Albert, but replaces the Self-Presence Thesis in Aquinas); see Cory 2014, chs. 1 and 6.

12 I am not convinced that the contemporary understanding of higher-order theories of consciousness maps perfectly onto medieval higher-order theories; however, the term serves well enough to indicate the kind of theory that is at hand.

13 On higher-order theories in later Scholasticism, see the introduction by Perler, Schierbaum 2014; Brower-Toland 2012; and Cross 2014, p. 52-57. 
this Higher-Order Thesis is already proposed sometime between $1245^{-1255}$ in Ps.-Henry's Liber commentary. In treating Ps.-Henry, I will discuss the HigherOrder Thesis in more detail.

With this historical-doctrinal context in hand, let us now turn to the individual theories of self-knowledge and reditio completa offered by both Liber commentaries. And in this regard, it is perhaps worth noting that there seem to have been in circulation in medieval Paris two variants of the Liber's prop. XIV(xv), which could be taken to have different implications for the Self-Presence Thesis.

Prop. $\operatorname{XIV}(\mathrm{XV}), \mathrm{v}_{1}$ : Every knower that knows its essence returns to its essence with a complete return (Omnis sciens qui scit essentiam suam est rediens ad essentiam suam reditione completa).

Prop. $\operatorname{XIV}(\mathrm{XV}), \mathrm{V}_{2}$ : Every knower knows its essence and therefore returns to its essence with a complete return (Omnis sciens scit essentiam suam, ergo est rediens ad essentiam suam reditione completa). ${ }^{14}$

$\mathrm{V}_{1}$, which seems to have been more widespread, leaves open the possibility that not all knowers know their essence. But $\mathrm{v}_{2}$ definitely closes off that possibility, and hence could easily serve as an articulation of the Self-Presence Thesis: the claim that every knower knows its essence could easily be taken to endorse a vision of self-knowing as necessary and essential to intellectual entities.

The text discussed in Ps.-Henry's commentary is clearly a version of $\mathrm{v}_{1}$ : "Everything knowing its essence returns to its essence (...)" (Omnis sciens essentiam suam est rediens $).{ }^{15}$ But it is not so clear which variant Bacon has in mind.

14 See text in note 17 below. $\mathrm{v}_{2}$, which is preserved in ms. Toledo, Biblioteca de la Catedral 97-1 among others, is less common. It is clearly the version that Aquinas followed in his Super Librum de causis, prop. $\mathrm{XIV}(\mathrm{xv})$, though not in his earlier quotations of the Liber's prop. XIV(XV). For discussion, see Cory 2017, p. 206-212.

15 It is worth noting though that Ps.-Henry holds that prop. $\mathrm{XIV}(\mathrm{XV})$ completes prop. XII(XIII)'s treatment of the self-knowledge by presence of intelligences. In other words, Omnis intelligentia intelligit essentiam suam has already been given the sense of the SelfPresence Thesis in commenting on prop. $\mathrm{XII}(\mathrm{XIII})$, and the sciens of prop. $\mathrm{XIV}(\mathrm{XV})$ is assumed to be an intelligence. So against that background, $v_{1}$ has much the same force as $\mathrm{V}_{2}$ on its own would have had. 
On the one hand, he formulates the first of his questions on the text as follows: "Whether everything that is knowing knows its essence" - a question that seems to arise more naturally given $v_{2}$ than $v_{1}$. On the other hand, the conclusion that Bacon draws seems to accord more with the spirit of $\mathrm{V}_{1}$ : As we shall see, he thinks that the embodied soul's self-presence entails that it can know its essence, but he does not state whether it therefore does know its essence. ${ }^{16}$ In any case, as mentioned above, both commentators accept the Self-Presence Thesis explicitly with respect to higher intelligences, but do not explicitly apply it to human souls.

Table 1 below provides a general overview of the structure of both commentaries' treatment of prop. $\operatorname{XIV}(\mathrm{xv})$. From the table, it is clear that there is certainly too much material here to be explored in just one take. So we will organize our quick tour through the texts in terms of just three interpretive puzzles with which the commentators grappled, arising from the lemma of prop. $\mathrm{XIV}(\mathrm{XV})$, namely: (i) Who or what is the sciens? (ii) How does the sciens know its own essence? (iii) What is a reditio, and when is it completa? Along the way we will see that a fourth puzzle concerning reflexivity is habitually raised in connection with the lemma of prop. $\operatorname{XIV}(\mathrm{XV})$ : (iv) Do the senses return to themselves?

I. TEXT OF THE LIBER DE CAUSIS, PROP. XIV(XV) (in the medieval Latin version)

[Lemma $v_{1}$ ] Every knower that knows its essence returns to his essence with a complete return. [Comment] The reason is that knowledge is nothing more than an intelligible action; therefore when a knower knows his essence, he then returns through his intelligible operation to its essence. And this is so only because the knower and the known are one thing, because the knowledge of one knowing his essence is from himself and toward himself: it is from himself, because he is a knower, and toward himself because he is the known. The reason is that, because knowledge is the knowledge of a knower, and the knower knows his essence, his operation is returning to his essence once again. And by 'the return of a substance to its essence' I do not mean anything other than that it is standing fixed by itself, not lacking in its fixity and its essence any other thing to strengthen it, because it is a simple substance, sufficient by itself. ${ }^{17}$

16 See text in note 22 below. Moreover, the path that the soul must take in order to know its essence, for Bacon, seems to have nothing to do with self-presence.

17 Liber de causis, prop. $\mathrm{XIV}(\mathrm{xv})$, p. 79-80: Omnis sciens qui scit essentiam suam est rediens ad essentiam suam reditione completa [alternate reading, $\mathrm{v}_{2}$ : Omnis sciens scit essentiam suam, ergo est rediens ad essentiam suam reditione completa.]. Quod est quia scientia non est nisi actio intellectibilis. Cum ergo scit sciens suam essentiam, tunc redit per operationem suam intellectibilem ad essentiam suam. Et hoc non est ita nisi quoniam sciens et scitum sunt res una, quoniam scientia scientis essentiam suam est ex eo et ad eum: est ex eo quia est sciens, et ad eum quia est scitum. Quod est quia propterea quod scientia est scientia scientis, 
(cont.)

\title{
II. THE COMMENTARIES: STRUCTURE AND SCOPE
}

\author{
Roger Bacon, Questiones supra Librum de Ps.-Henry of Ghent, Quaestiones in Librum \\ causis, c. 1245 \\ de causis, c. 1245-1255
}

List of questions Q1. "Whether every knower (omnis sciens) on prop. XIV $(X V)$ knows its own essence"-Yes.

Q2. "Whether every cognizer (omnis cognoscens), cognizes its own essence"No; senses are excluded due to their reliance on corporeal organs.

Q3. "Whether every knower returns to its own essence?"-No to a return qua substance; Yes to a return qua knowable.

Q4. "Whether every knower, returning to its own essence, returns to it with a complete return?"-Yes.

Q1. "Whether every knower (omnis sciens) of its own essence is returning to its essence"Yes, cognitively but not substantially. Q2. "Whether this is a returning by a complete return"-Yes.

Q3. "Whether the knower of its own essence can return upon its own act, namely, whether it knows that it knows its essence"-Yes.

Q4. "Whether the knower of its own essence needs any other thing in its fixity"-No, neither substantially nor cognitively.

Subject matter of The intellective soul in an embodied state prop. $X I V(X V)$

(with prop. XIII(XIV), forms a unit on the soul's cognition)

Intelligences existing separately from matter

(discusses reflexive self-knowledge / second act, completing the discussion of self-knowledge begun with prop. XII(XIII)'s treatment of self-knowledge per praesentiam / first act)

\section{DOCTRINE CONCERNING SELF-KNOWLEDGE AND REFLEXIVITY}

Types of self- $\quad$ (B1) In ratione cause: By reasoning from knowledge sensible effects to existence of the soul as cause;

(B2) In ratione essentie: A simple direct gaze at the soul's essence.

(B1) presupposes (B2). At no point does Bacon explicitly attribute to the soul a selfknowledge per praesentiam suam
(Ps-H1) Per praesentiam suam: Intelligere suam essentiam; simple cognition; = first act;

(Ps-H2) Per reflexionem ab actu ad essentiam: Reflexive self-knowing, intelligere se intelligere suam essentiam; composite cognition; = second act

(Ps-H1) presupposes (Ps-H2). Another type of reflexive self-knowledge, reasoning to

et sciens scit essentiam suam, est eius operatio rediens ad essentiam suam; ergo substantia eius est rediens ad essentiam ipsius iterum. Et non significo per reditionem substantiae ad essentiam suam, nisi quia est stans, fixa per se, non indigens in sui fixione et sui essentia re alia rigente [alternate: erigente] ipsam, quoniam est substantia simplex, sufficiens per seipsam. Note that Pattin's text is not a critical edition; some corrections by Richard Taylor have been printed in Fidora, Niederberger 2001, p. 34-148. 
(cont.)

\section{DOCTRINE CONCERNING SELF-KNOWLEDGE AND REFLEXIVITY}

one's essence from one's object as from effect to cause, is mentioned but dismissed as irrelevant.

Self-Presence Yes for intelligences (prop. XII(XIII)); self- Yes for intelligences (prop. XII(XIII)) Thesis presence of intellective souls implies merely that they are able to know themselves (prop. XII (Xv))

What is implied Distance, absence, having what one did by the term 'redi- not have before. tio'?

Is knowing one's own essence a reditio?

Return to one's essence "according to substance" (no); return to one's essence qua knowable (yes)

(B1) and (B2) are both reditiones ad essentiam suam
Distance, absence; circulatio $=$ moving through all the midpoints between termini on the way back

Distinction 1: return to one's essence "according to substance" (no); return to one's essence qua knowable (yes)

Distinction 2: moving through midpoints by reasoning (no); moving through midpoints all at once in one act (yes)

(Ps-H2) is a reditio ad essentiam suam; (PsH1) is not

What is completa Numerical identity of knower and known. All cognition is complete just in case the about the reditio completa? Both $(\mathrm{B} 1)$ and $(\mathrm{B} 2)$ are reditiones completae cognition itself is included in what is cog(Ps-H1) is an incomplete cognition; $\left(\mathrm{Ps}-\mathrm{H}_{2}\right)$ is a complete cognition.

Can senses have No. Yes, of Ps-H2-type, though only supra seipa reditio comsam is mentioned, not supra essentiam suam

pleta? 


\section{Roger Bacon: An attenuated Self-Knowledge for Embodied Souls}

\subsection{Two Kinds of Self-Knowledge}

Omnis sciens qui scit essentiam suam est rediens ad essentiam suam reditione completa. One of the challenges facing readers of the Liber's prop. XIV $(\mathrm{XV})$ was to decide who or what the sciens is. The context did not provide much help. Prop. XII(XIII), on the self-knowledge of intelligences (Omnis intelligentia intelligit essentiam suam) is the last in series of 7 propositions concerning "intelligences," i.e., intellects existing separately from matter. Prop. XIII(XIV) (In omni anima res sensibiles sunt per hoc quod sunt exemplum ei, et res intelligibiles in ea sunt, quia scit eas) turns to souls, addressing how souls know sensible and intelligible things.

Consequently, readers had to decide among a few options: (a) Do prop. XIII(XIV) and prop. XIV(XV) form a unified treatment of the soul's knowledge, first of things other than itself, and then of itself? And if so, does 'soul' refer to all souls, or to human souls only, or to the noble souls of the heavenly spheres only? Alternatively, (b), is prop. $\operatorname{xIV}(\mathrm{xv})$ supposed to be read together with prop. XII(XIII), as two parts of a single account of the self-knowledge of intelligences? Or (c) does prop. XIV(XV) address self-knowledge among "all knowers" in general, hence completing prop. XII(XIII)'s account of intelligences, while elucidating also the self-knowledge of souls?

Bacon seems to adopt option (a), focusing on the intellective soul in his comments on prop. $\operatorname{XIV}(\mathrm{XV}),{ }^{18}$ and more specifically on the embodied intellective

18 The text is on first view unclear. On the one hand, Bacon's examples of the sciens in Questiones supra Librum de causis 15, qq. 1-3 are always the intellective soul, and his solutions to the questions always reference the soul. On the other hand, the second argument of Questiones supra Librum de causis 15, q. 1 claims that the First Cause cannot know itself, in order to identify a counterexample to prop. XIV(XV)'s claim that omnis sciens scit essentiam suam; and the argument sed contra in Questiones supra Librum de causis 15, q. 4 mentions "soul or intelligence" (Reditio completa est que fit ab eodem in idem numero; set anima vel intelligentia in cognoscendo se reddit super seipsam eandem numero). But the overall development of the solutions from qq. 1-4 seems to weigh in favor of option (a). For instance, Bacon attributes to the sciens of prop. $\mathrm{XIV}(\mathrm{XV})$ a different kind of self-knowledge that could only be had by embodied intellectual entities (as I go on to show above). And although Bacon briefly responds to the argument that the First Cause cannot know its essence, nothing about Questiones supra Librum de causis suggests that his comments are intended to apply to it. We could conclude, then, that intelligences are included in the argument sed contra of Questiones supra Librum de causis 15, q. 4, not because souls and intelligences know themselves in the same way, but because Bacon is here defining what self-knowledge essentially is, i.e., a knowledge in which the origin and terminus, knower and known, are numerically one. In other words, both souls' self-knowing and intelligences' self-knowing 
soul or anima coniuncta..$^{19}$ The proposition thus treats our self-knowledge in the present state, which contrasts interestingly with the kind of self-knowledge assigned to intelligences. Commenting on prop. XII(XIII), Bacon had endorsed the Self-Presence Thesis with respect to intelligences. His reasoning is that the union of knower and known is sufficient for an act of knowing, and this union is secured inasmuch as the intelligence already is itself:

The act of understanding requires the following: one who understands, that which is understood, and the union of them. But the union of them can be had in two ways: either substantially or by a species. And the first kind of union is truer. Therefore because the union by a species suffices for the act of understanding, all the more does the substantial union suffice, because it is truer. And so 〈the intelligence〉 will cognize its essence by its presence. Which is to be conceded. For since its essence is presence to itself and within 〈itself〉, a species of itself would be superfluous for an act of cognizing its essence. ${ }^{20}$

In other words, an intelligence does not need any mechanism such as a species or likeness to unite it with itself, but rather "it cognizes its essence by its own presence."

When we turn to Bacon's comments on prop. $\operatorname{XIV}(\mathrm{XV})$, however, we find a more cautiously-formulated picture of the self-knowledge of the embodied intellective soul. ${ }^{21}$ In Questiones supra Librum de causis 15, q. 1 (on whether the soul knows its own essence), Bacon presents what seems at first glance to be

meet the criterion for a "complete return," although they do not have the same kind of self-knowing. Notice, however, that the First Cause is not said to return to its essence.

19 See the distinction in Questiones supra Librum de causis 13, q. 1, p. 70, l. 8-13: Ad objectum dicendum, quod duplex est intellectus; scilicet conjunctus corpori, ut intellectus hominis in hac vita [...] alius est intellectus liberatus a corpore, ut intellectus intelligentie vel anime separate. Also see Questiones supra Librum de causis 15, q. 1, discussing how the intellect's second kind of self-knowledge (see note 24 below) is very weak "in this life" - a phrase always referring to human beings before death.

20 Roger Bacon, Questiones supra Librum de causis 13, q. 2, p. 71, 1. 4-13: Set contra: ad actum intelligendi requiruntur ista, scilicet intelligens et intellectum et horum unio; set horum unio dupliciter potest esse; aut secundum substantiam, aut secundum speciem; et prima unio verior est, ergo cum unio secundum speciem sufficiat ad actum intelligendi, multo fortius unio secundum substantiam cum sit verior, et ita cognoscet suam essentiam per presentiam. Quod concedendum est, unde cum sua essentia sit sibi presens et intra superflueret sua species quoad actum cognoscendi suam essentiam.

21 Hence I do not think that the suggestion in D'Ancona 1995, that Bacon treats intelligences and intellective souls in the same way, can be maintained. 
the same argument for the Self-Presence Thesis that he had used to justify the self-knowledge of intelligences in commenting on prop. XII(XIII). But the conclusion is not quite the same:

Science is perfected by the union of the knowable with the one knowing, and sometimes this happens by 〈the latter's〉 union to a species of this knowable. But a union according to essence is truer than a union according to species. Therefore the soul will cognize and know (cognoscet et sciet) that which is united to it according to essence better than $\langle$ what is united to it $\rangle$ according to species. But to each one knowing, his own essence is united. Therefore every one that is knowing can cognize or know his own essence-which is to be conceded. ${ }^{22}$

The difference is slight, but significant: From the argument which in Questiones supra Librum de causis 13, q. 2, had produced the conclusion that intelligences do know their own essence "by their presence," Bacon draws here in Questiones supra Librum de causis 15, q. 1, the weaker conclusion that souls can know their own essence. A similar argument, again with this weaker conclusion, is drawn in Questiones supra Librum de causis 15, q. 2: "The intellective soul is intelligible and so is its essence. So, because the intellective soul is born to cognize intelligibles, therefore because it is a power of understanding, it can understand itself." 23

But does the insertion of this word, "can" (potest, poterit), indicate any meaningful theoretical difference between an embodied soul's self-knowledge, and an angelic intelligence's self-knowledge? On its own, perhaps not. But on closer scrutiny, a number of clues emerge, all pointing toward a distinction between the self-knowledge of embodied souls, and that of intelligences. Significantly, throughout Questiones supra Librum de causis 15, Bacon never attributes to the soul a self-knowledge "by its presence." Instead, he ascribes to us two kinds of self-knowledge, and repeatedly emphasizes the importance of the senses for both. In one kind $[=\mathrm{B} 1]$, the soul knows itself as a cause from its sensible effects. The other kind [= B2] is "very weak in this life": namely, the soul knows itself $a$ s an essence:

22 Roger Bacon, Questiones supra Librum de causis 15, q. 1, p. 79, 1. 22-30: Contra: scientia perficitur per unionem scilibis cum sciente, et hoc aliquando secundum unionem speciei ipsius scibilis; set verior est unio secundum essentiam quam secundum speciem, ergo magis cognoscet et sciet anima illud quod est ei unitum secundum essentiam quam secundum speciem; set unicuique scienti unita est sua essentia, ergo omnis sciens potest suam essentiam cognoscere vel scire. Quod concedendum est.

23 See Roger Bacon, Questiones supra Librum de causis 15, q. 2, in note 38 below. 
The soul can be considered in two ways, namely [B2] according to its essence and substance, and in this way it does not fall into sense; or [B1] according to its effects, and in this way it does fall into sense, and cognizes itself as a cause, from its effects. And when [the soul's] effects are cognized by their species, its intellect is fortified and strengthened in order to cognize itself first in as a cause, and consequently as an essence. For perhaps it may cognize itself first in the manner of the cause by the way of admiration, through its effects. But this will not suffice for its cognizing its own essence; rather, [for doing the latter] the intellect must be strengthened by cognizing the soul in the manner of a cause, in order to cognize itself as an essence, or in order to know its essence (ad sciendam suam essentiam). And this cognition is very weak in this life. ${ }^{24}$

The distinction between [B1] and [B2] is developed only briefly, and it is not immediately clear what its significance may be. But other passages provide some helpful interpretive clues.

For instance, immediately prior, in Questiones supra Librum de causis 14, q. 3, Bacon makes what seems to be a parallel distinction between two ways in which the soul knows "spiritual substances," i.e., intelligences. First, it knows them through their effects, as the causes of the motions of the heavens. Second, it knows them "insofar as they are substances standing by themselves," i.e., selfsubsisting immaterial substances. The first way is typical for humans in this life, whereas the second is "very weak, and as it were not included among the cognitions of the human soul, wherefore it is barely perceived on account of the certitude of something else."25 The first is acquired through the senses; while

24 Roger Bacon, Questiones supra Librum de causis 15, q. 1, p. 79, 1. 32-80, 1. 8: [A]nima potest considerari dupliciter; scilicet secundum sui essentiam et substantiam, et sic non cadit in sensu; vel secundum suos effectus, et sic cadit in sensu et cognoscitur in ratione cause a seipsa persuos effectus; cognitis suis effectibus per species suas fortificatur et vigoratur suus intellectus ad cognoscendum seipsam primo in ratione cause, et per consequens in ratione essentie; quia forte cognosceret seipsam primo in ratione cause via admirationis per effectus, set non sufficit ad hoc quod suam essentiam cognoscat, set oportet quod ulterius vigoretur intellectus cognoscens eam in ratione cause, ad cognoscendum eam in ratione essentie sive ad sciendum suam essentiam, et hec cognitio est valde debilis in hac vita.

25 Roger Bacon, Questiones supra Librum de causis 14, q. 3, p. 78, 1.17-28: Set dupliciter possunt $a b$ anima humana cognosci; scilicet vel in quantum sunt cause istorum inferiorum sensibilium et motus celi vel aliorum effectuum, et sic dico quod habent cognosci per suos effectus ab anima; vel in quantum sunt substantie per se stantes, et sic habent cognosci per species immissas quas imprimunt in animas nostras; sic loquitur Avicenna. Set prima cognitio est humana famose dicta et est certissima cognitio anime humane in hac vita, secunda vero est debilis valde et quasi non connumerata inter cognitiones anime humane, unde vix percipitur 
the second is had by species impressed by immaterial intelligences directly on the human soul. Crucially, the language for both distinctions is quite similar: e.g., knowing $x$ as a cause vs. as a substance; and knowing $x$ through the senses vs. "very weakly" in some other way. In both cases Bacon stresses that the context is "this life"-i.e., he is describing the knowledge of the anima coniuncta.

All this is curiously reminiscent of Bacon's broader view that in this life, we have both innate species and abstracted acquired species of bodily things. ${ }^{26} \mathrm{In}$ his Physics commentary, he explains that intellective souls, like intelligences, are full of all forms at the beginning (in other words, they originate with a complete set of innate species, like angels). But due to the "weight" of the body, ${ }^{27}$ and "distance from the first cause," those innate species are in it so confusedly that the human possible intellect "scientifically knows (scivit) nothing at all, but is rather a tabula rasa." ${ }^{28}$ Thus it still needs to acquire knowledge through the senses. As he explains in Questiones supra Librum de causis 14, q. 2, species abstracted from sense experience "are not superfluous in this life," because they provide a different kind of cognition: "In the human being there is a twofold cognition; a certain and determinate cognition that comes to be from acquired species; and another that precedes it, which is vague and confused, and this occurs by innate species and is the first human cognition." ${ }^{29}$

propter certitudinem alterius, et tamen fit, secundum Avicennam, et de hac dicitur primo Methaphysice quod intellectus noster se habet ad manifesta nature sicut oculus noctue ad lucem solis [= Aristotle, Metaphysics 2.1], et hec est considerationis Methaphysice et hic proprie habet determinari, alia autem cognitio in libro de Anima, quia intellectus naturalis ad eam aspirare non potest, unde due prime procedunt de hac debili cognitione. For the discussion of impressed knowledge, Bacon relies on Avicenna's Liber de philosophia prima sive scientia divina, III.8 (vol. 1, p. 16o-163), where Avicenna argues that we do not become essentially one with separate intelligences in knowing them; rather, we receive "impressions" from them. I am indebted to Olga Lizzini for locating this source.

26 I owe this connection to Rega Wood.

27 Roger Bacon, Questiones supra Physicorum 1, q. 15, p. 11, 1. 35-12, 1. 2: Unde licet de se omnia cognoscat in sua creatione, tamen obnubilatur in sui unione cum corpore.

28 Roger Bacon, Questiones supra Physicorum 1, q. 12, p. 9, 1. 2-7: Set in sua unione non omnia novit, immo habet cognitionem confusam et nihil penitus scivit possibilis, immo sicut tabula rasa, et hoc est propter elongationem ipsius a prima causa, set postea acquiritur in ipsa cognitio confusa [TC: From context one might have expected rather distincta, but perhaps the point is that one only becomes aware of this cognitio confusa later, as in Questiones supra Librum de causis 14, q. 3, cited in note 25 above].

29 Roger Bacon, Questiones supra Librum de causis 14, q. 2, p. 75, 1. 22-27: Vel etiam dicendum, quod in hac vita non superfluunt, quia in homine duplex est cognitio; quedam certa et determinata, et illa fit per species acquisitas; alia que hanc precedit que est confusa et vaga, et hec fit per species innatas, et hec est prima cognitio hominis. 
Now, finally, a pattern begins to emerge, which can help illuminate Bacon's distinction between the [B1] and [B2] types of self-knowledge from Questiones supra Librum de causis 15, q. 1. Whatever angelic intelligences have cognitively, intellectual souls also have, but in a different (confused) way while embodied. This is true of their innate or impressed species, as well as of their own self-presence. In all cases, the soul cannot benefit cognitively from what it has and must resort to discursive reasoning from sensible effects: The soul grasps material essences from their sensible properties, intelligences by their sensible effects, and itself also by its sensible effects.

I would suggest that the distinction in play here is between a properly intellective or intuitive mode of cognition (a direct experiential grasp of substances as they are in themselves), vs. a discursive mode of cognition (reasoning from effect to cause, tied to a dependence on sensation). The difference, perhaps, is akin to that between seeing a wolverine vs. knowing it indirectly as "whatever is leaving these footprints," or between seeing the Divine Essence in the beatific vision vs. reasoning to God's existence.

Now we can begin to see the significance of the distinction between [ $\left.\mathrm{B}_{1}\right]$ and [B2] types of self-knowledge. [B1] is an indirect, discursive self-knowledge: The soul reasons from its sensible effects to the conclusion that there is such a thing as a soul, just as one reasons that God exists from his sensible effects. This type of self-knowledge thus depends on sensation-presumably, our external sensations of our own living bodies. ${ }^{30}$

In contrast, $\left[\mathrm{B}_{2}\right]$ is a direct experiential self-intuition, in which the soul apprehends its own essence. Tentatively, I would suggest that [B2] is the embodied soul's version of the self-knowledge that an intelligence has per praesentiam suam. Interestingly, however, Bacon does not say that the soul has [B2] per praesentiam suam, nor does he say that $[\mathrm{B} 2]$ precedes [B1]. Instead, he makes [B2] somehow dependent on our intellect's being "strengthened" by acquiring [B1], i.e., somehow dependent on our reasoning from sense-experience! But it is worth noting that the same inverted order occurs in the parallel discussion of how intellective souls know intelligences. In Questiones supra Librum de causis 14, q. 3, quoted above, he calls our cognition of intelligences as substances

30 To the list of Aristotelian themes that D'Ancona (1995, p. 224-227) identifies in Bacon's and Ps.-Henry's commentaries, one might thus add (a) the principle that all knowledge comes through the senses, as well as (b) the program that Aristotle lays out (De anima 415a1522) for discovering the nature of the soul: i.e., reasoning from objects to acts to powers to the nature (more clearly referenced in Ps.-Henry; here in Bacon perhaps a version of this program underlies the idea that the soul grasps itself from its sensible effects). 
"very weak, and as it were not included among the cognitions of the human soul, wherefore it is barely perceived on account of the certitude of something else [emphasis added]."31

What Bacon seems to be saying is that although in an embodied state, the human soul has the apparatus for living the intuitive, intellective life of an intelligence (innate or impressed species, self-presence), this mode of cognition is inchoate and unusable within the framework of our ordinary embodied conscious life, requiring discursive reasoning in order to raise it to the level of a cognition, properly speaking (i.e., make it distinct). Applied to self-knowledge, the lesson would be that the soul's self-presence does not imply anything that rises to the level of a cognition, properly speaking. Once the soul has been strengthened by recognizing its own existence through reasoning as in $[\mathrm{B} 1]$, however, it can acquire (very weakly), the kind of direct self-intuition that intelligences have per praesentiam suam, which is what [B2] is.

If this way of distinguishing $\left[\mathrm{B}_{1}\right]$ and $\left[\mathrm{B}_{2}\right]$ is correct, then we can make the following observations about the historical significance of Bacon's treatment of self-knowledge in Questiones supra Librum de causis $\mathrm{XIV}(\mathrm{XV})$.

First, the text is striking for its reticence to endorse the Self-Presence Thesis for intellective souls. In this respect the treatment of the Questiones supra Librum de causis of the extent and scope of our embodied self-knowledge is more restrained, in comparison, e.g., with William of Auvergne just a decade earlier. $^{32}$

Second, Bacon's account of human self-knowledge corresponds in certain respects to a late-thirteenth-century caricature of Aquinas that Putallaz has identified in some of Aquinas's Franciscan critics. According to those critics, Aquinas holds that the human intellect knows itself only by reasoning from sensory experience - a view that they claimed amounted to rejecting the possibility of experiential self-awareness for human beings. ${ }^{33}$ In light of Bacon's procedure here, this misreading of Aquinas is now easier to understand: Something like this view had actually circulated in Paris, in Bacon's insistence on

31 Crowley 1950, p. 170-176, suggests that Bacon reluctantly allows for a kind of quasimystical moment in which the soul is able to grasp incorporeal things directly rather than through abstraction, once it has been strengthened by abstraction; Crowley suggests comparisons to some remarks about contemplation of pure forms in Adam of Buckfield, as well as the notion of intellectus adeptus in Al-Farabi.

32 See $§ 1$ above.

33 For discussion, see Putallaz 1991a, p. 131, n. 5o. I should note, however, that it is not always clear whether the Franciscan critics in question are worried about reasoning or simply an order of attention (see, e.g., the texts of Matthew of Aquasparta cited by Putallaz 1991b, p. 34-36). Against attributing this view to Aquinas, see Cory 2014, chs. 3-4. 
effect-to-cause reasoning as indispensable for human self-knowledge. And it bore superficial resemblances to Aquinas's, e.g., in its insistence on the priority of sensation in intellectual understanding, and inasmuch as Aquinas also describes a process of reasoning to a definition of the soul's essence in somewhat similar language.

\subsection{The Significance of the reditio completa}

Having shown two ways in which we can know our intellective soul and its essence, Bacon goes on in qq. 3-4 to justify calling the soul's knowledge of its own essence "a complete return to its own essence." The goal here is clearly to defend the language of reditio completa against Avicenna's objection in the Liber de anima v.7, that "nothing returns to its essence; for nothing is absent from its own essence." ${ }^{34}$ In fact, the first two arguments of q. 3 precisely echo Avicenna's objection, denying that self-knowledge can be construed a "return" since the language of "returning" implies a process of achieving union after an initial "distance" or "absence." (Analogously, the prodigal son can only be reasonably be said to "return to" his father if he has been "absent from" his father.)

In response, Bacon explains that one must distinguish between returning to one's essence substantially vs. cognitively. He agrees that I cannot depart from or be absent from my own essence according to substance (secundum substantiam), since this would imply a contradiction, namely, that I am not what I actually am. Nevertheless, one could be metaphorically "distant" or "absent" from oneself "as knowable" (in ratione scibilis), in the sense of first being ignorant of, then later knowing one's own essence. ${ }^{35}$ Intriguingly, the claim made

34 Avicenna, Liber de anima v.7, p. 168, 1. 41-169, 1. 46: Impossibile est etiam illud quod dicitur quod aliquid redeat ad suam essentiam; nihil enim absentatur ab essentia sua, sed fortassis dicitur eo quod aliquando absentetur ab actionibus quae sunt propriae ipsius, et quae perficiuntur ab ipsa sola: unde hoc non dicitur large nisi quia actiones non sunt ullo modo. Sed eius essentia quomodo non esset in seipsa? Sed certe de eius actionibus non deberet dici quod absententur ab illa: absens enim est in se, sed non est apud aliquid; hae autem actiones non sunt ullo modo nisi ea hora qua dat eis esse; non sunt ergo absentes ab ea. Essentia autem alicuius non absentatur ab eo nec redit ad illud. Could Avicenna have the Liber's prop. $\operatorname{XIV}(\mathrm{Xv})$ in mind? It is not impossible, but the textual evidence here is insufficient to prove such a thesis, since Avicenna also has access to the Theology of Aristotle, in which a reference to "returning to one's essence" also appears. On the question of whether Avicenna read the Liber de causis, see Olga Lizzini's chapter in this volume.

Roger Bacon, Questiones supra Librum de causis 15, q. 3, p. 81, 1. 28-33: Ad objectum primo dicendum, quod essentia dupliciter habet considerari; secundum se scilicet et absolute, et sic non distat ab eo cujus est essentia; vel in ratione scibilis, et sic bene potest distare ab eo cujus est essentia, et ita ad eam potest fieri reditio ab eo cujus est, non obstante unione secundum rem et substantiam. 
here- that it is possible to be united to my own essence ontologically without knowing my own essence - would seem to undermine the necessary link that Bacon establishes between self-presence and self-knowing in arguing for the Self-Presence Thesis in prop. XII(XIII). But he does not tell us anything here that would resolve the apparent contradiction. (Presumably the answer would lie in his broader view of embodiment as obscuring our innate knowledge, as discussed above.)

In any case, the reditio ad essentiam suam, for Bacon, is simply the soul's intellectual grasp of its own essence. Moreover, he adds in responding to q. 4, a return is "complete" (reditio completa) if the point "from which" and the point "to which" one returns are numerically identical (ab eodem in idem numero). In other words, there is a "complete return to one's essence" if and only if the knower successfully cognizes its very own numerically same essence. Bacon thus sees the Liber's reditio completa as consisting in a fully reflexive grasp of oneself such that one numerically single soul is at once knower and known. The numerical identity of knower and known, however, does not imply "completeness" in the sense of total self-comprehension. Indeed, Bacon appears to grant the claim made in Questiones supra Librum de causis 15, q. 4, arg. 1, that the embodied soul's self-knowledge, dependent as it is upon sensation, can never be "complete" in the sense of being perfectly comprehensive. "To the objection it must be said that there is a fallacia accidentis. For it is sufficient for a complete return, that from the same, it becomes [cognitively] the same in number. Whereas it is accidental to the complete return whether or not the cognition there is complete."36

\subsection{The Problem of Sensation}

Before leaving Bacon, we should notice a curious feature of his treatment: namely, his broadening of the discussion to investigate the ability of the senses to return to their essence (the Liber's prop. $\operatorname{xIV}(\mathrm{xv})$ never mentions the senses). In Questiones supra Librum de causis 15, q. 2, Bacon asks, evidently with the senses in mind, whether "everything that is cognizing cognizes its own essence" (here substituting the broader term cognoscens for sciens, which would be restricted to intellectual cognizers). The question is of considerable interest: Since sensation, unlike intellection, has a physical component, are the senses

36 Roger Bacon, Questiones supra Librum de causis 15, q. 4, p. 82, 1. 12-16: Ad objectum dicendum, quod ibi est fallacia accidentis quoniam ad reditionem completam sufficit quod fiat ab eodem idem numero; quod autem sit ibi cognitio completa, hoc accidit ipsi reditioni complete, et ita est ibi fallacia accidentis. 
capable of the kind of full reflexivity in which cognizer is numerically identical with the cognized? Is the sensitive soul properly a self-knower?

Bacon's treatment of q. 2, however, is disappointingly brief and even routine. The opening arguments, which he will reject, take the same approach that he had previously used to establish that intelligences always know themselves, and that intellective souls can know themselves: namely, what is present to the soul in its being is better known than what is extrinsic to the soul. ${ }^{37}$ Bacon responds that the sensitive soul cannot cognize its essence, because cognition requires not only the presence, but also the proportionality, of the object to the cognizer. Thus since the proper object of a sense-power is the sensible, "the essence of [the sense-power] itself is not sensible." ${ }^{38}$ The argument does not turn, as one might at first suppose, on the sense-power's inability to grasp essences, but rather on its inability to grasp what is non-sensible (i.e., nonphysical). This becomes clear from the argument sed contra, which denies that the sense-power can grasp itself, i.e., a particular: "No power bound to an organ can return upon its essence, but the sensitive power is just such [a power], which is why it cannot cognize itself." Interestingly, this argument seems to locate the obstacle to sensory reflexivity in the sense as cognizer ("the power bound to an organ") rather than in the sense's lack of sensible qualities as object of sense. Since Bacon merely concedes the argument without comment, however, none of these issues can be explored.

In any case, the message is clear: The reditio ad suam essentiam is restricted to intellectual entities. Indeed, it seems that by introducing a question about sense reflexivity in q. 2, Bacon merely intends to justify the limited scope of the Liber's prop. $\mathrm{XIV}(\mathrm{XV})$, which addresses intellectual entities (sciens).

37 For instance, the second argument of Roger Bacon, Questiones supra Librum de causis 15 , q. 2, p. 8o, 1. 23-26 runs as follows: Anima sensitiva magis est sibi-ipsi unita quam rebus sensibilibus extra; set illarum sibi acquirit cognitionem, ergo multo magis sue essentie cognitionem habebit.

38 Roger Bacon, Questiones supra Librum de causis 15, q. 2, p. 8o, 1. 33-81, 1. 4: Ad objectum dicendum, quod presentia et indistantia non sufficit ad cognitionem, set oportet quod sit virtus talis que possit in tale objectum cognoscendum, scilicet in seipsam in ratione objecti, quod non est in proposito, quoniam virtus anime sensitive limitata est et coartata est ad cognoscendum sensibilia solum, ejus autem essentia non est sensibilis, et ideo suam essentiam cognoscere non potest. Set anima intellectiva est intelligibilis et similiter ejus essentia; quoniam anima intellectiva nata est cognoscere intelligibilia, ideo cum sit virtus intelligens poterit seipsam intelligere. It is odd that Bacon does not mention this additional condition in his discussion of the intellective soul's self-knowledge in q. 1 . 
In his Quaestiones in Librum de causis, prop. $\mathrm{XIV}(\mathrm{XV})$, Ps.-Henry adopts many of Bacon's concepts and distinctions. But as we will see, he significantly reconceives them, due to a fundamental difference in how these two authors situate prop. $\mathrm{XIV}(\mathrm{XV})$ in the broader context of the Liber. Bacon reads prop. $\mathrm{XIV}(\mathrm{XV})$ as the continuation of prop. XIII(XIV)'s discussion of intellective souls. But Ps.Henry reads prop. $\mathrm{XIV}(\mathrm{XV})$ as developing prop. XII(XIII)'s discussion of the selfknowledge of separate intelligences, so that props. XII(XIII) and $\mathrm{XIV}(\mathrm{XV})$ each present one of the two ways in which intelligences can understand themselves.

These two ways are outlined clearly by Ps.-Henry in Questiones supra Librum

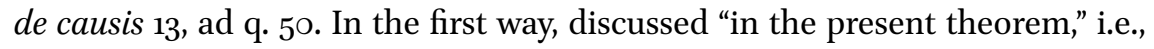
prop. XII(XIII), an intelligence understands itself "by a simple understanding (intellectu simplici), namely by its presence" (Ps- $\mathrm{H} 1$; and this formulation makes clear that Ps.-Henry accepts the Self-Presence Thesis). In the second way, to be discussed "in a later theorem," i.e., prop. $\operatorname{XIV}(\mathrm{XV})$, an intelligence understands itself "by a reflexive understanding" (intellectu circumflexo) (Ps-H2). The first kind is unmediated, but the second kind occurs "through a medium" (per medium) in the sense that it occurs either by the intelligence's power, or by its power and act together. ${ }^{39}$ In order to explain the difference between the two kinds of self-knowledge, Ps.-Henry makes striking use of Aristotle's first act / second act distinction:

As it is said in the second book of De anima, 'to live' (vivere) is said in many ways: for in one way, to live is to be, and in another way, it is to operate- and there it is said that to live is to be moved, to understand,

39 Ps.-Henry of Ghent, Questiones supra Librum de causis 15, ad q. 5o, p. 126, 1. 75-127, 1. 91, responding to the question of whether intelligences know themselves "through some medium" (per medium): Intelligentia se intelligit dupliciter principaliter: uno modo intellectu simplici, scilicet per sui praesentiam; alio modo intellectu circumflexo, et hoc dupliciter: uno modo reflectendo se supra suam essentiam absolute; alio modo reflectendo se supra suam essentiam et suam actum. Loquendo de intellectu intelligentiae primo modo, dicendum quod intelligit essentiam suam absque medio, scilicet per sui praesentiam. Loquendo de intellectu secundo modo, intelligit ipsam per medium. Sed primo illorum modorum intelligit ipsam mediante virtute: extendendo enim quasi extra se per eius virtutem, reflectendo $\langle$ se supra〉 suam essentiam intelligit seipsam. Secundo illorum modorum intelligit se mediante virtute et eius actu, ut intelligentia intelligit aliud a se per suam virtutem: intelligendo $\langle$ se $\rangle$ intelligere alia a se, reflectendo suum actum supra seipsam tamquam ad suam causam, cognoscit suam essentiam et isto modo cognoscit se per suos effectus. De intellectu primo modo principaliter datur illa propositio. De intellectu secundo modo dabitur inferius theorema. 
and to sense. [...] But because for intelligences, to live is to understand (intelligentibus vivere est intelligere), just as for those that are sensing, to live is to sense, and for those vegetating, to live is to vegetate, it must be said that for intelligences 'to understand' is twofold: for there is a certain understanding (intelligere) that is being (esse), which is their first act; and there is an understanding (intelligere) which is operation (operari), which is second act. Understanding in the first sense is from the substance of the intelligence and by such an act of understanding, the intelligence understands its essence with a simple understanding. But understanding in the second way alone is a second act proceeding from a power, which is what the objection addresses. But this understanding is not the topic of the present theorem, but of the following. ${ }^{40}$

In explicating the intelligence's first kind of self-knowledge through the Aristotelian notion of "first act," Ps.-Henry comes close to saying that the very being (esse) of an intelligence just is a certain kind of self-understanding! This is not an unreasonable conclusion to draw from the Self-Presence Thesis, but he is one of the few Scholastic authors that take this step explicitly. If my reading is correct, then, it would place him in line with some recent interpretations of Avicenna, e.g., Deborah Black's and Jari Kaukua's. ${ }^{41}$

In any case, it is the second kind of self-knowing - the intelligence's "second act," a reflexive and mediated self-knowing — which is, for Ps.-Henry, relevant to the Liber's prop. $\mathrm{XIV}(\mathrm{XV})$. In commenting on prop. $\mathrm{XIV}(\mathrm{XV})$, he further divides reflexive self-knowing into two sub-types, the first of which, as it seems, is to be identified with the reditio completa of prop. $\operatorname{XIV}(\mathrm{Xv})$ :

40 Ps.-Henry of Ghent, Questiones supra Librum de causis 13, ad q. 5o, p. 127, l. 93-109: Dicendum secundum quod dicit $I^{\circ}$ De anima: vivere dicitur multipliciter: vivere uno modo est esse, alio modo est operari; et ibi dicitur quoniam vivere 〈est〉 moveri, intelligere et sentire. Secundum hoc dicendum quod vivere $\langle$ primo modo $\rangle$ sit simpliciter vivere, scilicet quod est esse; vel aliud vivere viventibus est esse, ut vivere quod $\langle$ est $\rangle$ operari. Vivere particulariter similiter dicitur dupliciter. Cum intelligentibus autem vivere est intelligere, sicut in sentientibus vivere est sentire et in vegetantibus suum vivere est vegetari, dicendum quod in intelligentibus intelligere est duplex: est enim quoddam intelligere quod est esse, quod est actus primus ipsorum, et est intelligere quod est operari, quod est actus secundus. Intelligere primo modo est a substantia intelligentis et tali actu intelligendi intelligit intelligentia suam essentiam intellectu simplici: cum enim suum intelligere fit ex praesentia sui a se, et hoc consistit in suo esse, suum esse est suum intelligere intellectu tali simplici. Intelligere vero secundo modo solum est actus secundus egrediens a virtute, de quo processit obiectio. Sed de isto intelligere non est sermo in praesenti theoremate, sed in sequente.

41 Black 2008, p. 66: "The self just is awareness: for the self to exist at all is for it to be aware of itself" (distinguished from a second-order self-awareness, $76-78$ ); Kaukua 2015, p. 43-61. 
〈The intelligence's self-cognition by reflexion〉 occurs by its power, with the power mediating, by cognizing its operation or its object, and returning from that cognized thing to its 〈i.e., the intelligence's> own essence, as from an effect to a cause. This is the kind of reflexion that is under discussion in this proposition. And this reflexion can occur in two ways: in one way, by returning to its own essence from the act alone, and in another way by returning to its substance from the act and object. The first return happens when the intelligence understands its essence, and in doing so, understands that it understands its essence by that act of understanding returning once again to its essence. And this is the kind of cognition with which this discussion is concerned. Whence this cognition by return presupposes a simple cognition, and because of this the proposition continues: every knower of its own knowledge returns to it (omnis sciens scientiam suam redit ad ipsam). In another way, $\langle$ a reflexion $\rangle$ happens by returning to the essence from operation and object, as when the intelligence understands things other than itself and then, understanding that it understands them, or that they are caused by it, returns to its own essence by cognizing itself as 〈their〉 cause. But this return does not presuppose a simple cognition. So it is not properly the topic of discussion for the present proposition. So one ought to affirm that "whatever is knowing its essence, etc." - and that this occurs by the act's reflexion upon itself in 〈the intelligence's > cognizing that it knows its own essence, and $<$ whence it returns $\rangle$ from $\langle$ the act $\rangle$ to its essence, which is principally known. ${ }^{42}$

42 Ps.-Henry of Ghent, Questiones supra Librum de causis 15, ad q. 55, p. 139, l. 68-88: Alia est cognitio intelligentiae de seipsa per reflexionem. Et hoc fit per eius potentiam, mediante ipsa, cognoscendo suam operationem aut eius obiectum et ab illo cognito redeundo supra suam essentiam tamquam per effectum ad causa. De tali reflexione est sermo in hoc theoremate. Et potest fieri ista reflexio dupliciter: uno modo redeundo ab actu solo ad suam essentiam; alio modo redeundo ad substantiam ab actu et obiecto. Prima reditio fit cum intelligentia intelligit suam essentiam et hanc intelligendo, intelligit se intelligere suam essentiam ab illo actu intelligendi iterum redeundo supra suam essentiam. Et de tali cognitione proprie est hic sermo. Unde talis cognitio per reditionem praesupponit cognitionem simplicem et propter hoc datur theorema per impletionem: omnis sciens scientiam suam redit ad ipsam. Alio modo fit per reditionem ab operatione et obiecto supra essentiam, ut quando intelligentia intelligit alia a se et tunc intelligendo se intelligere illa vel illa esse causata ab ipsa, redit ad suam essentiam, ipsam cognoscendo tamquam causam. Talis autem reditio non praesupponit cognitionem simplicem. Unde nec proprie de ipsa est sermo in praesenti theoremate. Sic ergo dicendum quod omnis sciens suam essentiam, etc., et hoc per reflexionem sui actus supra seipsum in cognoscendo se scire suam essentiam et ab illo ad suam essentiam principaliter scitam $\langle$ redeundo $\rangle$. 
The key distinctions are easily lost in the avalanche of cumbersome terminology. The point, I think, is just this: There is a kind of "return to one's substance" (the second sub-type, or the "return from act and object") that presupposes an act of cognizing something other than oneself, and that the author excludes from the scope of prop. $\operatorname{XIV}(\mathrm{XV}) \cdot{ }^{43}$ The other kind of "return to one's substance" (the first sub-type, or the "return from act only") is equated with the reditio completa properly speaking, and presupposes the simple "first act" of self-understanding that had been described in prop. XII(XIII).

So what exactly is this reditio completa, according to Ps.-Henry? The author associates "returning" with mediacy, on the grounds that "returning" implies passing from a starting-point through a "middle" back to the starting-point. ${ }^{44}$ In one sense, this mediacy has to do with how the reflexive act is produced: namely, as we saw from the beginning of the text just cited, the intelligence produces this operation through a power, not directly from its own substance (unlike its "first act" consisting in self-knowing by self-presence). In other words, the intelligence is in potency to its second act, such that its self-knowing substance is prior to its operation of reflexive self-knowing. ${ }^{45}$ Thus Ps.-Henry follows Bacon in insisting that the "return to one's essence" implies an operational, not an ontological, distance from oneself. An intelligence is in no way ontologically "distant" from its own substance, but it can be operationally distant in the sense of lacking an act of understanding its substance-specifically, the act of reflexive self-understanding, which is its second act with respect to its own substance. ${ }^{46}$

43 Although Ps.-Henry subsequently seems to agree that this second sub-type counts as a kind of return to one's essence, it is "less complete" because self-cognition is "truer" than cognition of other things, which is presumably why he excludes it from the scope of prop. XII(XV). Ps.-Henry of Ghent, Questiones supra Librum de causis 15, ad q. 56, p. 140, l. 102108: Cum enim reditio talis fit a cognitione suae operatinis ad cognitionem suae substantiae, cognitio suae operationis quae cadit supra seipsam est perfectissima, secundum quod verius cognoscit seipsam quam alia a se. Secundum hoc ergo reflexio supra suum actum in se et ab illo redeundo ad substantiam suam facit reditionem completiorem quam reflexio supra suum actu intelligendo alia a se.

44 Ps.-Henry of Ghent, Questiones supra Librum de causis 15, q. 56, p. 138, 1. 38-39: Non est reditio completa nisi quae fuit per $\langle$ transitum $\rangle$ super omnia media inter terminos. In his ad q. 56, Ps.-Henry grants the ratio ad istam partem, not the conclusions drawn from it (p. 140, l. 110).

45 See note 46 below.

46 Ps.-Henry of Ghent, Questiones supra Librum de causis 15, ad q. 55, p. 139, 1. 91-140, 1. 99: Sed duplex est distantia et absentia alicuius ab alio: aut secundum rem et substantiam, aut secundum rem et eius actum. Primo modo, ut arguebatur, sciens essentiam suam non a se distat, nec est sibi absens. Sed secundo modo, in quantum intelligit intelligere suam essentiam, 
But there also seems to be another sense in which the reditio completa is mediated: namely, in contrast to the "first act" in which the intelligence's essence is intellectually present to itself, in the reditio completa the intelligence understands its essence through understanding its act: "returning from its act alone to its essence." Now one might at first assume that Ps.-Henry is describing a process of reasoning to one's essence, similar to Bacon's notion of "returning to one's essence as cause by reasoning from sensible effects." But Ps.-Henry insists that although it is true that in "returning to one's essence, one must go through everything that is in the middle between the termini," reflexive selfknowing goes through "all the midpoints that fall into a cognition of what is the same as itself, because such cognition occurs by a simple act." ${ }^{\prime 4}$ The idea seems to be that whereas reasoning involves a progression step by step from cognizing the act to (separately) cognizing the essence, the reditio completa consists of a single act that encompasses act and essence all together at once in a single act of reflexive self-knowing.

But then what exactly is the difference between "understanding one's essence" (the intelligence's first act) and "understanding one's understanding of one's essence" (the second act or reditio completa)? The answer appears in q. 57's contra argument (which Ps.-Henry endorses), which lays down as a general principle that in order to know any object, $x$, completely, one must know one's knowing of $x$.

quoad suum actum intelligendi suam substantiam 〈distat〉 et est quodammodo absens a se. Talis autem distantia et absentia requiritur ad reditionem talem, de qua est hic sermo, ut visum est.

47 Ps.-Henry of Ghent, Questiones supra Librum de causis 15, q. 56, p. 138, l. 38-42: Non est reditio completa nisi quae fuit per 〈transitum〉 super omnia media inter terminos. Sed sciens essentiam suam, in sciendo essentiam suam, non transit media, per quae idem suam essentiam natum est cognoscere. Ergo sciens essentiam suam, in quantum huiusmodi, non est rediens ad ipsam reditione completa. In ad q. 56, Ps.-Henry of Ghent responds (p. 140, l. 111119): Ad illud quod arguitur in oppositum quod ista reditio non fit per omnia media etc., dicendum quod falsum est, immo fit per omnia media quae cadunt in cognitione eiusdem a se, quoniam talis cognitio fit per suuam actum simplicem. Et talis reditio fit reflectendo suum actum supra se, ut visum est. Non autem fit per media quae sunt in alio genere cognitionis, scilicet reditione secundo modo, secundum quod obieciebatur. Nec tamen hoc causat aliquam incompletionem, quia, cum reditio sit quaedam circulatio, sua circulatio consistit in transitu super propria media. Depending on how we interpret media qua sunt in alio genere cognitionis, we might also construe Ps.-Henry as being concerned here to deny that one of the relevant "midpoints" in the reditio completa is an extramental object. In fact, in the first part of the response ad q. 56 , he insists that reditio completa is an act of reflexively knowing one's own essence; although reflexive knowledge of other things is possible, it is less perfect (p. 140, l. 106-108): Secundum hoc ergo reflexio supra suum actum in se et 
Everything that has complete cognition, for instance concerning its own essence, by a complete operation, is returning upon its essence with a complete return. [...] For it is clear that in some beings, the operation is not completed unless it reflects upon itself, because sight is not completed unless it sees that it sees, as is said in De anima $\mathrm{II}^{48}$

In other words, something crucial is missing from my cognition of $x$ if I fail to grasp my own act of cognizing. My sight of a tree is incomplete unless I "see my seeing of a tree"; and I understand treeness incompletely if I do not understand my understanding of treeness.

I would argue that what Ps.-Henry has in mind here is a distinction between mere cognitive activity and consciousness of something, addressing the third problem we saw earlier, namely, "what counts as a full, attentive cognition of $x$ ?" In other words, he invokes a version of the Higher-Order Thesis, according to which the cognition of $x$ is insufficient for the consciousness of $x$, which additionally requires cognizing one's cognition of $x$. Recall that according to the Higher-Order Thesis, merely having an act of "understanding triangularity" is not enough for being aware of triangularity. In order to be aware of triangularity, I must produce a higher-order act of understanding that encompasses the lower-order act of understanding triangularity. In other words, "being aware of triangularity" is equivalent to "understanding my understanding of triangularity." Or to put it another way, I can be aware of triangularity just in case I apprehend triangularity as understood by me.

Moreover, it is noteworthy that Ps.-Henry takes care to insist that what is "principally understood" in this reflexive act is not the intellectual act itself but the intelligence's own essence qua understood. ${ }^{49}$ This added precision is quite significant in terms of an account of self-consciousness. If the reflexive act had as its principal object the simple act of self-understanding itself, then the reflex-

ab illo redeundo ad substantiam suam facit reditionem completiorem quam reflexio supra suum actum intelligendo alia a se.

48 Ps.-Henry of Ghent, Questiones supra Librum de causis 15, q. 56, arg contra, p. 138, l. 50-57: Omne quod completam habet cognitionem, ut de sui essentia, per eius operationem est rediens supra essentiam suam reditione completa [...] patet secundum quod in aliis operatio non completur nisi reflectatur supra seipsam, quiat visus non completur nisi videat se viderem, ut $\langle\text { habetur }\rangle_{I I}$ De anima. This is conceded in ad q. 56, p. 140, 1. 101-110. And in ad q. 57 (p. 142, l. 55-59), Ps.-Henry repeats scientia scientis est actio intelligibilis et sic sciens essentiam suam poterit scire se scire suam essentiam. Aliter enim non compleretur actus sciendi. Et per talem scientiam rediens est reditione completa ad suam essentiam, secundum quod exponit Commentator.

49 See the final sentence in the passage cited in note 39 above. 
ive act would be an act of thinking about the simple act. Instead, the reflexive act has the intelligence's essence as its principal object (just as the simple act does, presumably). The difference between the simple and reflexive acts, then, is that they grasp the same object differently: in the reflexive act, the intelligence grasps its own essence as understood in the simple act, and hence is properly speaking aware of its essence. Hence Ps.-Henry describes the reflexive act as "composite," presumably to underscore that it includes the simple act, and the essence as cognized by the simple act. ${ }^{50}$

To summarize: for Ps.-Henry, then, the reditio completa seems to be a higherorder or complex act of reflexive self-knowing performed by intelligences. They "return" thereby to their essence insofar as such acts are originally "absent from" (not included in) the substance of an intelligence. And this return is "complete" insofar as reflexive self-knowing is an awareness of one's essence, i.e., a composite, higher-order act encompassing not only one's own essence, but also the simple, first-order act of understanding one's own essence. We can thus see that Ps.-Henry's distinction between first act (simple cognition) and second act (composite, reflexive cognition) in knowing one's essence has turned out to correspond to the distinction between a first-order knowing of one's own essence, and the second-order knowing one's knowing one's own essence. ${ }^{51}$

Ps.-Henry's comments on prop. XIV(Xv) leave much unclear, such as whether any of these types of self-knowledge can also be attributed to the human intellective soul. ${ }^{52}$ Nevertheless, his ingenious and unusual remarks deserve

50 In Questiones supra Librum de causis 15, q. 57, an objection complains that if "understanding one's understanding of one's essence" is made the criterion of cognitive completeness, then there could be no complete cognition. For "understanding one's understanding of one's essence" will itself be incomplete unless one "understands one's understanding of one's understanding of one's essence," and so on to infinity. Ps.-Henry responds (p. 143, l. 66-71): Quod arguebatur secundo quod, si intelligeret se intelligere suam essentiam, actus intelligendi procederet in infinitum, dicendum quod non oportet, eo quod in secundo actu, scilicet intelligendo se intelligere, totaliter actio intelligendi completur, quia per ipsam cognoscit intelligible. Est enim prima cognitio cognitio simplex; secunda autem est composita terminata ad simplicem.

$5^{1}$ If I am reading Ps.-Henry correctly, then, he thus advocates the kind of view that Putallaz attributes to Thomas Aquinas (Putallaz 1991a, p. 148-208, esp., e.g., 154; for my objections to that interpretation of Aquinas, see Cory 2014, p. 166-170).

$5^{2}$ He draws a contrast between intelligences and "the conjoined soul" in ad q. 58, which seems to suggest that embodied human souls at least do not have any "immediate understanding of their essence" (p. 143, l. 94-96)—so the self-knowing in first act "by one's presence" seems to be denied to the anima coniuncta, as it was in Bacon. But Ps.-Henry leaves unstated whether we can practice reflexive self-knowing and/or reason to the soul's essence as cause. But a case can be made that he wished to attribute the latter to embodied souls, by undoing what I believe to be an error in the text. After contrasting intelligences, 
further study. For one thing, they bear witness that a higher-order theory of consciousness - the center of the 14th-century debate about consciousnesswas being defended as early as the 1240s-1250s. Moreover, the version in which this theory appears is, although abbreviated, particularly sophisticated and interesting. Ps.-Henry's formulation of the Higher-Order Thesis makes it possible to answer a question that arises from the Self-Presence Thesis, but which so many of his predecessors simply glossed over: namely, self-knowing per praesentiam in first act is a "blind" or unconscious self-knowing precisely one understands one's essence without any reflexive awareness of that understanding itself. This "simple cognition" or first-order unconscious essential self-understanding is "completed" or elevated into the sphere of consciousness when incorporated into a "composite cognition" or higher-order act. And the implied parallel drawn between the Aristotelian first-act / second-act distinction, and the "simple" (first-order) act / "composite" (higher-order) act is, I think, significant, though space is too short to develop this idea here.

It is worth noting that although Ps.-Henry does not pose the question of whether the senses are capable of a "complete return," some of the arguments that he apparently accepts explicitly state that sensation is "completed" by reflecting on itself:

Just as the sensitive power is related to its act, so too is the intellective related to its act. For the sensitive power senses itself sensing (sentit se sentire), just as sight sees itself seeing, and hearing hears itself hearing: otherwise the act of seeing would not be completed, as it is said in $D e$ anima 2. Therefore what is intellective, such as an intelligence, understands itself understanding (intelligit se intelligere). ${ }^{53}$

who have everything they need internally to understand themselves or other things, with embodied souls, quae ad hoc quod intelligat eget phantasmatibus, Ps.-Henry goes on to say (p. 143, 1. 87-91): Et tunc valet eius expositio ad propositum: quia enim intelligentia est fixa in intelligendo, poterit complete a suo actu redire ad suam essentiam, quia non potest se intelligere nisi per collationem ab obiectis ad suam substantiam. The second half of the sentence (quia non potest se intelligere [...]) seems inconsistent with everything he has just said about the self-knowledge of intelligences. But the sentence becomes perfectly intelligible if we assume that the subject of the second half of the sentence is anima coniuncta, and that the reportatio of Ps.-Henry's lecture mistakes Ps.-Henry's contrast for an explanation. If that is the case, then Ps.-Henry would be denying to the anima coniuncta all self-knowledge other than a reasoning to its own essence from its sensible effects, consistent with the view we saw in Bacon.

53 Ps.-Henry of Ghent, Questiones supra Librum de causis 15, q. 57, p. 149, 1. 25-29: Praeterea, sicut se habet virtus sensitiva ad suum actum, et intellectiva ad suum actum. Virtus autem 
The view described here seems to amount to saying that sensation is conscious because it is "complete" in the sense of reflexive: i.e., it performs a higherorder act that encompasses its own first-order act of sensation. It is interesting to note the resonances with Aquinas's short-lived attempt, a few years later in De veritate, to accord to the senses an "incomplete return to themselves" - but not to their essences. ${ }^{54}$

By way of concluding, I would like to offer a few brief remarks on the broader historical significance of the theories of self-knowledge and reditio completa that we have just considered. It is interesting to notice that a number of distinctions from Bacon's remarks on prop. XIV(XV) reappear in Thomas Aquinas's earliest discussions of prop. $\mathrm{XIV}(\mathrm{XV})$ only a few years later, in his Commentary on the Sentences (1252-1256) and in his Quaestiones disputatae de veritate (1257-1259), both written in Paris. Whether or not this should be taken as evidence of direct influence, it does at least suggest that in the late 1240 s and early 125os, the Liber's prop. $\mathrm{XIV}(\mathrm{XV})$ was being associated with a certain set of concepts or distinctions, which are similarly construed in both Aquinas and Bacon. (One cannot say anything more definitive before an in-depth study of the reception of prop. $\mathrm{XIV}(\mathrm{XV})$ in Albert's early works.) Some examples:

First, Bacon (but not Ps.-Henry) identifies the reditio with a process of reasoning, which is "complete" in the sense that knower and known are numerically identical, in the way in which a loop is complete because the end of the thread touches its beginning. Similarly, Aquinas's tendency in his early years in Paris is to treat the reditio completa as a discursive reasoning to the soul's essence. ${ }^{55}$ Second, Bacon justifies the language of reditio by explaining that one returns to one's essence as knowable, not ontologically "according to thing and substance" (secundum rem and substantiam). The same distinction between cognitive and substantial "returning" appears in Aquinas, although Aquinas identifies substantial returning with "ontological fixity," enabling him to say

sensitiva sentit se sentire, ut visus videt $\langle$ se $\rangle$ videre et auditus audit se audire: aliter enim non compleretur actus videndi, ut $\langle\text { habetur }\rangle_{I I}$ De anima. Ergo virtus intellectiva, ut intelligentia, intelliget se intelligere.

55 Thomas Aquinas, Commentary on the Sentences I.17.1.15, ad 3; De veritate 1.9; De veritate 10.9. The framing of reditio as discursive reasoning is most explicit in De veritate 2.2, ad 2; see note 53 below. 
that in some sense there is a reditio completa in God. ${ }^{56}$ Third, both Bacon and Ps.-Henry remark on whether the senses, like intellect, are reflexive, i.e., cognizing themselves, their essences, or their own acts. ${ }^{57}$ In doing so, they go outside the scope of the Liber's prop. $\operatorname{XIV}(\mathrm{XV})$. Likewise, in Aquinas's early writings, the Liber's prop. $\mathrm{XIV}(\mathrm{XV})$ consistently surfaces in connection with intellectual reflexivity, which is then compared to sense reflexivity. In his commentary on the Sentences, Aquinas defends the view we saw in Bacon, denying that sense can in any way return to itself. But in his De veritate, he adopts the view we saw in Ps.-Henry, arguing that sense can return to its act (which Aquinas calls, strikingly, a reditio incompleta). Elsewhere I have suggested doctrinal reasons for this inconsistency of opinion on sense reflexivity, which continues to waver throughout his career. ${ }^{58}$ But we can now see that Aquinas did not reason through the issue in a vacuum: Both views were already circulating at

$5^{6} \quad$ Thomas Aquinas, De veritate 2.2, ad 2, p. 45, 1. 205-229: [L]ocutio haec qua dicitur, quod sciens se, ad essentiam suam redit, est locutio metaphorica; non enim in intelligendo est motus, ut probatur in VII Physicorum. Unde nec, proprie loquendo, est ibi recessus aut reditus; sed pro tanto dicitur ibi esse processus vel motus, in quantum ex uno cognoscibili pervenitur ad aliud; et quidem in nobis fit per quemdam discursum, secundum quem est exitus et reditus in animam nostram, dum cognoscit seipsam. Sed in divina cognitione non est aliquis discursus, ut prius dictum est, quasi per notum in ignotum deveniat. Nihilominus tamen ex parte cognoscibilium potest quidam circuitus in eius cognitione inveniri; dum scilicet cognoscens essentiam suam res alias intuetur, in quibus suae essentiae similitudinem videt, et sic quodammodo ad suam essentiam redit, non quasi suam essentiam ex rebus aliis cognoscens, sicut in nostra anima accidebat.

57 Thomas Aquinas, Commentary on the Sentences I.17.1.5, ad 3, p. 406: [I]n potentiis materialibus hoc contingit quod potentia non reflectitur super suum actum, propter hoc quod determinata est secundum complexionem organi. Visus enim particularis non potest cognoscere nisi illud cujus species spiritualiter in pupilla potest recipi; et ideo visus non potest comprehendere suum actum [...]. Et ideo dicendum, quod potentiae immateriales reflectuntur super sua objecta; quia intellectus intelligit se intelligere, et similiter voluntas vult se velle et diligit se diligere [...] et propter hoc Liber de causis, prop. 15, dicitur quod cujuscumque actio redit in essentiam agentis per quamdam reflexionem, oportet essentiam ejus ad seipsam redire, idest in se subsistentem esse, non super aliud delatam, idest non dependentem a materia. In II.19.1.1, p. 481-482, listing arguments for the separability and incorruptibility of the human soul: Tertio, quia intellectus intelligit se; quod non contingit in aliqua virtute cujus operatio sit per organum corporale [...]. Unde cum non sit possibile ut organum corporale cadat medium inter virtutem aliquam et ipsam essentiam virtutis, non erit possibile ut aliqua virtus operans mediante organo corporali cognoscat seipsam. Et haec probatio tangitur in Libro de causis in illa propositione 15: 'Omnis sciens qui scit essentiam suam, est rediens ad essentiam suam reditione completa.' Et dicitur redire complete ad essentiam, ut ibi Commentator exponit, cujus essentia est fixa stans, non super aliud delata. Ex quibus omnibus patet quod anima intellectiva habet esse absolutum, non dependens ad corpus; unde corrupto corpore non corrumpitur.

$5^{8}$ Cory 2017, p. 187-193. 
Paris and available for him to choose from. Fourth, finally (though this does not have to do specifically with interpretations of the Liber's prop. $\operatorname{XIV}(\mathrm{XV})$ ), we see that in toning down the implications of the human soul's self-presence for its self-knowing, while enthusiastically defending the Self-Presence Thesis with respect to intelligences, Bacon and Ps.-Henry anticipate Aquinas's rather unusual and explicit rejection of actual self-knowledge per essentiam with respect to the human soul, in De veritate (1257-1258).

As I have shown elsewhere, however, Aquinas's interpretation of the Liber de causis, prop. $\mathrm{XIV}(\mathrm{XV})$, changed significantly after his encounter with Proclus's Elementatio theologiae in 1268. In his late commentary on the Liber (written 1272), he now interprets the reditio as the soul's operation of knowing its own essence, an operational return which "completes" the substantial return that is the soul's self-subsistence. Here his new interpretation turns out to be now closer to that of Ps.-Henry. ${ }^{59}$ Those resonances, however, may be purely coincidental, as Aquinas rigorously defends his new interpretation by appealing, convincingly enough, to propositions from Proclus's Elementatio theologiae.

In fact, it is difficult to find any trace of Bacon and Ps.-Henry in prop. XIV(Xv) of Aquinas's Liber commentary (or for that matter, in the Liber commentary of Siger of Brabant, dating from c. 1273-1276, which is significantly, though in no way slavishly, influenced by Aquinas's commentary). In the case of Aquinas, the translation of Proclus's Elementatio demanded an abandonment of the previous interpretive tradition in favor of a complete reworking of the interpretation of the Liber's reditio completa. The only remaining trace of the earlier conceptual framework that I can find is in Aquinas's modified version of Bacon's distinction between a substantial vs. a cognitive return to one's essence, which we had already seen him defending in his earliest writings. However, Bacon's and Ps.-Henry's interpretations likewise have no overlap at all with Albert's interpretation of prop. $\operatorname{XIV}(\mathrm{XV})$ in his own Liber commentary (composed probably in Würzburg sometime between 1264-1267).

I speculate, then, that although Bacon's reading of prop. $\operatorname{XIV}(\mathrm{XV})$ was quickly taken up and reconceived by Ps.-Henry, and appears to have circulated at Paris at least to the extent of being picked up by the early Aquinas, Bacon's construal of the reditio completa as the soul's discursive reasoning to its numerically same self did not remain influential much longer. Its interpretive legitimacy could not have seemed plausible once Proclus's Elementatio had been translated. Per-

59 Though certainly not identical: Aquinas does not portray the act in question as a higherorder act, and he construes prop. $\mathrm{XIV}(\mathrm{XV})$ as applying to souls, not intelligences. 
haps, too, the cumbersome type of self-knowledge it attributed to the soul also seemed out of fashion in a debate that placed increasing importance on psychologically sophisticated treatments of self-awareness. In any case it met an ignominious end in the mockery of the late 13th-century Franciscans who confused it with Aquinas's view that the intellect cognizes itself "by its acts." But the concept with which Ps.-Henry associated the reditio completa - a higher-order or complex act of cognizing one's cognizing $x$, which "completes" the cognition of $x$ by raising it into the sphere of consciousness-became the centerpiece of theories of self-consciousness into the 14 th century. ${ }^{60}$

\section{Bibliography}

\section{Manuscripts}

Toledo, Biblioteca de la Catedral, Ms 97.1.

\section{Primary Sources}

Albert the Great, De homine, ed. H. Anzulewicz, J.R. Söder, ed. Colon. vol. 27/2, Cologne, Aschendorff, 2008.

Albert the Great, Super I Sententiarum, ed. A. Borgnet, vol. 1, Paris, Ludovicum Vivès, 1893 .

Augustine, De trinitate libri XV, ed. W.J. Mountain, Turnhout, Brepols, 1963.

Avicenna, Liber de philosophia prima sive scientia divina, ed. S. Van Riet, Leiden, Brill, 1977 .

Avicenna, Liber de anima, seu sextus de naturalibus, ed. S. Van Riet, Leiden, Brill, 19681972.

Bonaventure, Commnentarius in I librum Sententiarum, Opera omnia vol. 1, Quaracchi, Collegium S. Bonaventurae, 1882.

Ps.-Henry of Ghent, Les Quaestiones in Librum de causis, ed. J.P. Zwaenepoel, Louvain, Publications universitaires, 1974.

Jean de la Rochelle, Summa de anima, ed. J.G. Bougerol, Paris, Vrin, 1995.

Liber de causis, in A. Pattin (ed.), Miscellanea, vol. 1, Leuven, Bibliothek van de Facultiet Godgeleerdheid, 2000.

Roger Bacon, Questiones supra Librum de causis, in Opera hactenus inedita Rogeri Baconi, vol. 12, ed. R. Steele, F.M. Delorme, Oxford, Clarendon Press, and vol. 13, Questiones supra libros octo Physicorum Aristotelis, ed. F.M. Delorme, R. Steele, Oxford, Clarendon Press, 1935 .

6o See literature in note 13 above. 
Thomas Aquinas, Scriptum super libros Sententiarum magistri Petri Lombardi episcopi parisiensis, vols. 1-2, ed. P. Mandonnet, Paris, P. Lethielleux, 1929.

Thomas Aquinas, Quaestiones disputatae de veritate, ed. Leon. vol. 22, ed. A. Dondaine, Rome, Editori di san Tommaso, 1972-1976.

Thomas Aquinas, Super Librum de causis expositio, ed. H.-D. Saffrey, Paris, Vrin, 2002.

William of Auvergne, De anima, in Opera omnia, vol. 2, Paris, Pralard, 1674.

\section{Secondary Sources}

Baumgarten, A. (2014), "Reditio completa. Connaissance et réflexivité dans quelques commentaires latins sur le Livre des causes", in Transylvanian Review 23, p. 2347 .

Black, D. (2008), "Avicenna on Self-Awareness and Knowing that One Knows", in S. Rahman et al. (eds), The Unity of Science in the Arabic Tradition, Dordrecht, Springer, p. $63-87$.

Brower-Toland, S. (2012), "Medieval Approaches to Consciousness: Ockham and Chatton", in Philosopher's Imprint vol. 12, no. 17, p. 1-29.

Cory, T.S. (2014), Aquinas on Human Self-Knowledge, Cambridge, Cambridge University Press.

Cory, T.S. (2017), "Reditio completa, reditio incompleta: Aquinas and the Liber de causis, prop. 15 on Reflexivity and Incorporeality", in A. Fidora, N. Polloni (eds), Appropriation, Interpretation and Criticism: Philosophical Exchanges Between the Arabic, Hebrew and Latin Intellectual Traditions, FIDEM-Textes et Études du Moyen Âge 88, Barcelona / Rome, Brepols, p. 185-229.

Cross, R. (2014), Duns Scotus's Theory of Cognition, Oxford, Oxford University Press.

Crowley, T. (1950), Roger Bacon: The Problem of the Soul in His Philosophical Commentaries, Louvain, Editions de l'Institut Supérieur de Philosophie.

D’Ancona, C. (1995), "Philosophus in Libro de causis: Le Liber de causis comme ouvrage aristotélicien dans les commentaires de Roger Bacon, du Ps-Henri de Gand, et du Ps-Adam de Bocfeld", in Id., Recherches sur le Liber du Causis, Paris, Vrin, p. 195227.

Donati, S. (2013), "Pseudoepigrapha in the Opera hactenus inedita Rogeri Baconi? The Commentaries on the Physics and on the Metaphysics", in J. Verger, O. Weijers (eds), Les débuts de l'enseignment universitaire à Paris (1200-1240 environ), Turnhout, Brepols, p. 153-203.

Fetz, R.L. (1975), Ontologie der Innerlichkeit: Reditio completa und processio interior bei Thomas von Aquin, Fribourg, Universitätsverlag Freiburg.

Fidora, A., Niederberger, A. (eds) (2001), Von Bagdad nach Toledo: Das Buch der Ursachen und seine Rezeption im Mittelalter. Lateinisch-deutscher Text, Kommentar und Wirkungsgeschichte des Liber de Causis, Mainz, Dieterichsche Verlagsbuchhandlung. 
Hackett, J. (2015), "Roger Bacon", in E.N. Zalta (ed), The Stanford Encyclopedia of Philosophy, Retrieved from https://plato.stanford.edu/archives/spr2015/entries/rogerbacon/.

Kaukua, J. (2015), Self-Awareness in Islamic Philosophy: Avicenna and Beyond, Cambridge, Cambridge University Press.

Köhler, T. (2000), Grundlagen des philosophisch-anthropologischen Diskurses im dreizehnten Jahrhundert: die Erkenntnisbemühungen um den Menschen im zeitgenössischen Verständnis, Leiden, Brill.

Pattin, A. (2000), Miscellanea, vol. 1, Leuven, Bibliotheek van de Facultiet Godgeleerdheid.

Perler, D., Schierbaum, S. (eds), (2014), Selbstbezug und Selbstwissen. Texte zu einer mittelalterlichen Debatte, Frankfurt am Main, Klostermann.

Putallaz, F.-X. (1991a), Le sens de la réflexion chez Thomas d'Aquin, Paris, Vrin.

Putallaz, F.-X. (1991b), La connaissance de soi au XIII ${ }^{e}$ siècle: de Matthieu d'Aquasparta à Thierry de Freiberg, Paris, Vrin.

Still, C.N. (1999), "Aquinas's Theory of Human Self-Knowledge", Ph.D. Diss., University of Toronto, Centre for Medieval Studies.

Wrobel, J. (1979), "Le problème reditio dans la XIVème proposition du commentaire de Roger Bacon au Liber de causis," in Actas del V Congreso internacional de filosofía medieval, vol. 2, Madrid, Editora Nacional, p. 1371-1375. 